\title{
Problem-Solving in MS Excel as a Method of Some Key Competences Developing During the Study of Chemistry, Mathematics and Informatics in Secondary School Institutions
}

\author{
Semchuk A., Yuzkova V. ${ }^{*}$ \\ Chernivtsi In-Service Teacher Training Institute, Chernivtsi, Ukraine
}

Received: 24.09 .2019

Accepted: 21.12 .2019

\begin{abstract}
The article analyses the competence potential of current syllabi in chemistry (Years 7-9), mathematics (Years 5-9) and informatics (Years 5-9), including syllabi for Year 9 students of general secondary education institutions (GSEI) with an in-depth study of mathematics/chemistry, from the standpoint of equivalence of all key competencies at all stages of study proclaimed by the New Ukrainian School. The topics that can be successfully used to implement the competency-based approach and optimize the learning process due to interdisciplinary integration according to the proposed algorithm are identified. The algorithm steps are: on the basis of the chemical/economic problem, mathematical model variables are introduced and described; a mathematical model is created; mathematical model solution is found using Solver add-in of the spreadsheet program MS Excel; the numerical solution is interpreted in terms of the problem being solved. This approach contributes to the development of mathematical, information and digital competencies, competencies in natural sciences and technologies, initiative and entrepreneurship as key competencies of the New Ukrainian School during the educational process in mathematics, chemistry and informatics in Year 9 of GSEI. The described algorithm for problem-solving is proposed to be applied to problems connected with calculating a mass fraction of a solute in a solution formed by mixing several solutions (typical chemical problems on the topic "Calculations related to the composition of solutions") and tasks involving the concept of percentage or mass ratio of components of the mixture/alloy formed from two or more input mixtures/alloys (typical algebraic problems on the topic "Percentage calculations"). The authors demonstrate potential of the developed algorithm use for optimization economic problems solving in order to implement the crosscutting content line "Entrepreneurship and financial literacy" in the informatics educational process (the topic "Creating and processing models using examples of tasks from different subject areas in various software environments"). Three tasks were solved and illustrated with screenshots, and the new, clear to students, approach for solving systems of linear algebraic equations using MS Excel spreadsheets (they are traditionally proposed to be solved using not studied in school inverse matrix) was proposed.

Key words: mathematical modeling, integration of science and mathematics disciplines, New Ukrainian School, competence in math, competences in natural sciences and technologies, information and digital competence, initiative and entrepreneurship.
\end{abstract}

\section{Розв'язування задач у MS Excel, як спосіб розвитку деяких ключових компетентностей, під час вивчення хімії, математики та інформатики у $33 \mathrm{CO}$}

\author{
Семчук А. Р., Юзькова В. Д. \\ Інститут післядипломної педагогічної освіти Чернівецької області, Чернівці, Україна
}

\begin{abstract}
Анотація. У статті здійснено аналіз компетентнісного потенціалу діючих навчальних програм з хімії (7-9 класи), математики (5-9 класи) та інформатики (5-9 класи), зокрема, програм для учнів 9-х класів закладів загальної середньої освіти (33СО) з поглибленим вивченням математики/хімії, з позицій проголошеної Новою українською школою рівнозначності усіх ключових компетентностей на всіх етапах навчання. Визначено теми, які можна успішно використовувати для реалізації компетентнісного підходу та оптимізації процесу навчання
\end{abstract}

Corresponding Author: Yuzkova Valentyna Dmytrivna. Tel. 0952464709. E-mail: uzkovav@ukr.net Chernivtsi In-Service Teacher Training Institute, Franko str., 20, Chernivtsi, Ukraine, 58000.

Відnовідальний автор: Юзькова Валентина Дмитрівна. Тел. 0952464709. E-mail: uzkovav@ukr.net Інститут післядипломної педагогічної освіти Чернівецької області, вул. Франка, 20, м. Чернівці, Україна, 58000. 
шляхом міжпредметної інтеграції за таким алгоритмом: виходячи з умови хімічної/економічної задачі, вводяться та описуються змінні майбутньої математичної моделі; створюється математична модель; розв'язок одержаної математичної задачі знаходиться за допомогою надбудови Пошук розв'язку табличного процесора MS Excel; одержаний числовий розв'язок інтерпретується у термінах розв'язуваної прикладної задачі. Такий підхід сприяє розвитку математичної та інформаційно-цифрової компетентностей, компетентностей у природничих науках і технологіях та ініціативності і підприємливості як ключових компетентностей Нової української школи під час навчального процесу з математики, хімії та інформатики у 9x класах 33СО. Описаний у статті алгоритм розв'язування задач пропонується застосовувати до завдань на обчислення масової частки розчиненої речовини у розчині, утвореному внаслідок змішування кількох вихідних розчинів (типові хімічні задачі з теми «Обчислення, пов'язані зі складом розчинів») та завдань, що включають поняття відсоткового вмісту або масових відношень компонентів суміші/сплаву, що утворюється 3 двох чи більше вихідних сумішей/сплавів (типові алгебраїчні задачі з теми «Відсоткові розрахунки»). Також авторами продемонстровано можливість застосування розробленого алгоритму для розв'язування оптимізаційних задач економічного змісту з метою реалізації наскрізної змістової лінії «Підприємливість та фінансова грамотність» у навчальному процесі з інформатики (тема «Створення і опрацювання моделей на прикладах задач з різних предметних галузей в різних програмних середовищах»). У роботі розв'язано і проілюстровано скріншотами три задачі, а також запропоновано новий, зрозуміліший учням, підхід до розв'язання системи лінійних алгебраїчних рівнянь з використанням електронних таблиць MS Excel (у літературі традиційно пропонується розв'язувати їх з використанням оберненої матриці, що не вивчається в школі).

Ключові слова: математичне моделювання, інтеграція природничо-математичних дисциплін, Нова українська школа, математична компетентність, інформаційно-цифрова компетентність, компетентності у природничих науках і технологіях, ініціативність і підприємливість.

\title{
Решение задач в MS Excel, как способ развития некоторых ключевых компетентностей, при изучении химии, математики и информатики в YOCO
}

\author{
Семчук А. Р., Юзькова В. Д. \\ Институт последипломного педагогического образования Черновицкой области, Черновцы, Украина
}

\begin{abstract}
Аннотация. В статье проанализирован компетентностный потенциал действующих учебных программ по химии (7-9 классы), математике (5-9 классы) и информатике (5-9 классы), в том числе, программ для учащихся 9-х классов учреждений общего среднего образования (УОСО) с углубленным изучением математики/химии, с позиции провозглашенной Новой украинской школой равнозначности всех ключевых компетентностей на всех этапах обучения. Определены темы, которые можно успешно использовать для реализации компетентностного подхода и оптимизации процесса обучения путем межпредметной интеграции по следующему алгоритму: исходя из условия химической/экономической задачи, вводятся и описываются переменные будущей математической модели; создается математическая модель; решение полученной математической задачи находится с помощью надстройки Поиск решения табличного процессора MS Excel; полученное числовое решение интерпретируется в терминах решаемой прикладной задачи. Такой подход способствует развитию математической и информационно-цифровой компетентностей, компетентностей в естественных науках и технологиях, а также, инициативности и предприимчивости как ключевых компетентностей Новой украинской школы во время учебного процесса по математике, химии и информатике в 9-х классах УОСО. Описанный в статье алгоритм решения задач предлагается применять к задачам на вычисление массовой доли растворенного вещества в растворе, образованном в результате смешивания нескольких исходных растворов (типичные химические задачи по теме «Вычисления, связанные с составом растворов») и задач, включающих понятие процентного содержания или массовых отношений компонентов смеси/сплава, образующийся из двух или более выходных смесей/сплавов (типичные алгебраические задачи по теме «Процентные расчеты»). Также авторами продемонстрирована возможность применения разработанного алгоритма для решения оптимизационных задач экономического содержания с целью реализации сквозной содержательной линии «Предприимчивость и финансовая грамотность» в учебном процессе по информатике (тема «Создание и обработка моделей на примерах задач из разных предметных областей в различных программных средах»). В работе решено и проиллюстрировано скриншотами три задачи, а также предложен новый, понятный ученикам, подход к решению системы линейных алгебраических уравнений с использованием электронных таблиц MS Excel (в литературе традиционно предлагается решать их с использованием обратной матрицы, что не изучается в школе).

Ключевые слова: математическое моделирование, интеграция естественно-математических дисциплин, Новая украинская школа, математическая компетентность, информационно-цифрровая компетентность, компетентности в естественных науках и технологиях, инициативность и предприимчивость.
\end{abstract}




\section{Bcmyn}

У концепції НУШ значна увага приділяється реалізації компетентнісного підходу в освіті через формування десяти ключових компетентностей здобувача освіти, що передбачає зміщення акцентів навчання із накопичення знань, формування умінь і навичок на вироблення і розвиток умінь діяти, застосовувати набутий досвід у конкретних життєвих ситуаціях.

Важливий акцент змін у концепції НУШ пов'язаний із тим, що визнається рівнозначність усіх ключових компетентностей на всіх етапах навчання. Тобто кожна освітня галузь має освітній потенціал, необхідний для формування кожної ключової компетентності. Цей потенціал має бути реалізований наскрізно у процесі вивчення кожного предмета або курсу [1].

3 огляду на вищезазначене, впровадження компетентнісного підходу повинно відбуватися у тісному взаємозв'язку з процесами інтеграції навчальних дисциплін. Важливою умовою інтеграції природничо-математичних та технологічних дисциплін $€$ застосування методу моделювання. У процесі моделювання об'єктів із області природознавства, якісно нового характеру набувають інтеграційні зв'язки, які об'єднують різні галузі знань. Цей метод дозволяє, з одного боку, зрозуміти структуру різних об'єктів; навчитися прогнозувати наслідки впливу на об'єкти дослідження і керувати ними; а з іншого боку - оптимізувати процес навчання, розвивати ключові компетентності [2].

Отже, актуальним є дослідження, пов'язані із застосуванням методу математичного моделювання 3 метою реалізації компетентністного підходу через міжпредметну інтеграцію хімії, математики та інформатики.

Meта роботи: продемонструвати можливість застосування методу математичного моделювання задач та знаходження їх розв'язків у середовищі табличного процесора MS Excel в якості інтегрованого підходу до формування деяких ключових компетентностей НУШ, а саме: математичної, інформаційноцифрової компетентностей, компетентностей у природничих науках і технологіях та ініціативності і підприємливості під час вивчення хімії, математики та інформатики у 9-их класах 33СО.

\section{II Матеріал і методи дослідження}

У роботі були використані загальнонаукові методи дослідження: аналіз, синтез та моделювання. Метод аналізу застосований для вивчення змісту діючих навчальних програм з хімії, математики та інформатики для учнів 7-9 класів 33СО, а також сутності понять математичної, інформаційно-цифрової компетентностей, компетентностей у природничих науках та технологіях та ініціативності та підприємливості згідно визначень поданих у концепції НУШ та у програмах з конкретних дисциплін. Синтетичний метод та метод моделювання використано для розробки загального алгоритму, який можна застосовувати для розв'язування прикладних задач під час вивчення певних тем з хімії, математики та інформатики з метою формування зазначених ключових компетентностей.

Розпочнемо із розгляду математичної компетентності як однієї із ключових компетентностей НУШ. Математична компетентність включає культуру логічного і алгоритмічного мислення; уміння застосовувати математичні (числові та геометричні) методи для розв'язування прикладних задач у різних ссрерах діяльності; здатність до розуміння і використання простих математичних моделей та уміння будувати такі моделі для вирішення проблем [3].

Предмет хімія відкриває широкі можливості для розвитку математичної компетентності учнів. Згідно навчальної програми «Хімія, 7-9 класи» для 33СО, математична компетентність під час вивчення хімії передбачає оволодіння здобувачами освіти таких умінь: застосовувати математичні методи для розв'язування завдань хімічного характеру; використовувати логічне мислення, зокрема, для розв'язування розрахункових і експериментальних задач, просторову уяву для складання структурних формул і моделей речовин; будувати і тлумачити графіки, схеми, діаграми, складати моделі хімічних сполук і процесів [4].

На нашу думку, одним із найсприятливіших типів хімічних задач для фрормування математичної грамотності учнів $33 \mathrm{CO} є$ задачі з тем «Кількісний склад розчину. Масова частка розчиненої речовини» (7-й клас), «Розчини» (9-й клас, рівень стандарту), «Кількісний склад розчину. Масова частка розчиненої речовини» та «Обчислення, пов'язані зі складом розчинів» (9-й клас, рівень поглибленого вивчення хімії). Ці задачі пов'язані із використанням поняття масової частки розчиненої речовини у водному 
розчині, масових часток компонентів у суміші твердих, рідких або газоподібних речовин чи масових часток компонентів у сплаві. Добре розвиває математичну компетентність учнів, а саме «здатність до розуміння і використання простих математичних моделей та уміння будувати такі моделі для вирішення проблем», розв'язування дещо складніших задач із зазначеної теми, в яких розчин (або сплав) утворюється в результаті змішування двох і більше вихідних розчинів (сплавів) з однаковим якісним, але різним кількісним складом.

Зазначимо, що задачі, пов'язані з обчисленням масової частки компонента у розчині, суміші чи сплаві, наявні також у шкільному курсі алгебри 7-го класу у межах теми «Лінійні рівняння та їх системи як математичні моделі текстових задач» та курсі алгебри 9-го класу для учнів 33СО з поглибленим вивченням математики в рамках теми «Відсоткові розрахунки» як задачі на визначення відсоткового вмісту певного компонента в суміші або розчині. Такі задачі у курсі математики сприяють формуванню в учнів основних компетентностей у природничих науках та технологіях, які, згідно навчальної програми «Математика, 5-9 клас», передбачають розвиток наступних умінь: вивчати і розпізнавати проблеми, що виникають у довкіллі і які можна розв'язати засобами математики; будувати та досліджувати математичні моделі природних явищ і процесів [5].

Проте способи, які пропонують учням вчителі математики для розв'язування таких задач, відрізняються від тих, що зазвичай використовуються вчителями хімії, що порушує цілісність сприйняття учнями навчального матеріалу та перешкоджає успішному формуванню математичної компетентності на уроках хімії та компетентностей у природничих науках і технологіях під час вивчення математики. Вчителі хімії частіше застосовують синтетичний метод та «правило діагоналей», натомість вчителі математики надають перевагу алгебраїчному методу. Але, як правило, вчителі не використовують комп'ютерну техніку для розв'язування задач, а, отже, нехтують однією з можливостей розвитку інформаційно-цифрової компетентності, яка передбачає «впевнене, а водночас критичне застосування інформаційно-комунікаційних технологій для створення, пошуку, обробки, обміну інфрормацією..., володіння основами програмування...» [3]. Причому фрормування інформаційно-цифрової компетентності під час вивчення курсів математики та хімії прописано у відповідних навчальних програмах і передбачає розвиток наступних умінь: структурувати дані; діяти за алгоритмом та складати алгоритми; визначати достатність даних для розв'язання задачі; використовувати різні знакові системи; знаходити інформацію та оцінювати ії достовірність; доводити істинність тверджень [5]; використовувати сучасні пристрої для одержання хімічної інформації, її обробки, збереження i передавання; створювати інформаційні продукти хімічного змісту [4].

Задачі на визначення масової частки компонента у суміші, сплаві чи розчині, на нашу думку, можна також розв'язувати на уроках інформатики під час вивчення у 9-му класі теми «Створення і опрацювання моделей на прикладах задач з різних предметних галузей (фізика, математика, хімія, біологія тощо) в різних програмних середовищах» (розділ «Комп'ютерне моделювання») [6] з метою посилення формування однієї із ключових компетентностей НУШ - компетентності у природничих науках і технологіях. Зазначимо, що ця компетентність передбачає, зокрема, «наукове розуміння природи і сучасних технологій, а також здатність застосовувати його в практичній діяльності» [3], а отже використання задач на визначення масової частки у навчальному процесі з інформатики сприятиме ії формуванню. Враховуючи, що наявні підручники з інформатики для учнів 9-го класу практично не містять прикладних задач з хімії, а отже приділяють недостатньо уваги розвитку хімічної складової компетентності у природничих науках та технологіях, створення простих математичних моделей хімічних задач та їх розв'язування засобами табличного процесора MS Excel сприятиме реалізації компетентнісного підходу в освіті.

\section{III Результати}

Практичне впровадження запропонованого підходу продемонструємо на прикладах (задачах) з підручників хімії та математики для 9 класу.

Задача 1. У двох сплавах маси міді та цинку відносяться як $5: 2$ і $3: 4$. Скільки треба взяти кілограмів першого сплаву та скільки другого, щоб, сплавивши їх, отримати 28 кг нового сплаву 3 рівним вмістом міді й цинку? [7] 
Створимо математичну модель задачі 1. Для цього позначимо масу першого сплаву, яку використаємо при створенні нового сплаву, через $x_{1}$ (кг), а другого - через $x_{2}$ (кг). Тоді їх сума повинна дорівнювати масі нового (третього) сплаву, а це означає, що повинна виконуватися рівність $x_{1}+x_{2}=28$. Маса міді у третьому сплаві рівна сумі мас міді, яка міститься в $x_{1}$ (кг) першого сплаву та в $x_{2}$ (кг) другого сплаву, тобто сумі $\left(\frac{5}{7} x_{1}+\frac{3}{7} x_{2}\right)$, аналогічно маса цинку $-\left(\frac{2}{7} x_{1}+\frac{4}{7} x_{2}\right) .3$ умови задачі вміст міді та цинку у третьому сплаві має бути однаковим, тобто $\frac{5}{7} x_{1}+\frac{3}{7} x_{2}=\frac{2}{7} x_{1}+\frac{4}{7} x_{2}$. Помноживши останню рівність на 7 та звівши подібні члени, отримаємо таке рівняння $3 x_{1}-x_{2}=0$. За умовою задачі, одержані рівняння повинні виконуватися одночасно, тому математична модель нашої задачі має вигляд:

$$
\left\{\begin{array}{c}
x_{1}+x_{2}=28 \\
3 x_{1}-x_{2}=0 \\
x_{1} \geq 0, x_{2} \geq 0 .
\end{array}\right.
$$

Зауважимо, що останні дві умови (нерівності) є природними, оскільки маси двох використаних сплавів не можуть бути від'ємними.

Розв'язок математичної задачі (1) знайдемо, скориставшись надбудовую Пошук розв'язку електронних таблиць Microsoft Excel (у деяких версіях цю надбудову називають Розв'язувач, а в російськомовних інтерфейсах Поиск решения або Решебник). У новому електронному аркуші Microsoft Excel створюємо електронний шаблон для розв'язання систем лінійних алгебраїчних рівнянь (СЛАР), показаний на рис. 1. Для кращого розуміння зробимо пояснення до рис. 1. У математичній моделі $x_{1}-$ маса першого сплаву, яку використаємо для створення нового сплаву, тобто $x_{1}$ - це два в одному: означає перший сплав і маса (число) цього сплаву, тому в третьому рядочку, починаючи із стовпчика $\mathrm{F}$, вказано назви змінних, а у четвертому - їхні числові значення. Починаючи з сьомого рядочка і далі, вказуються дані про кожне рівняння СЛАР згідно інформації, яка вказана у шостому рядочку.

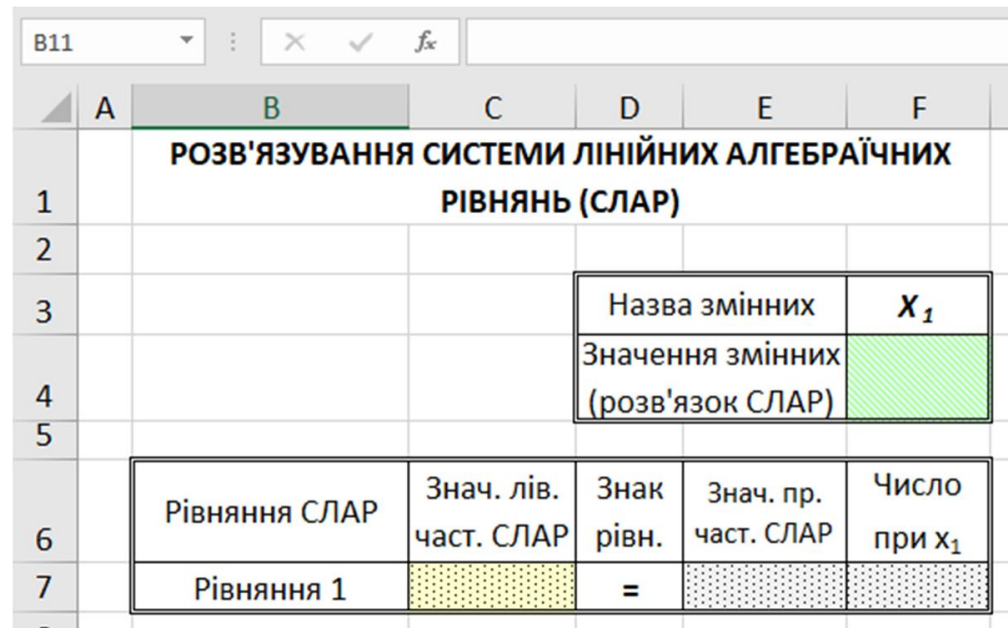

Рис. 1. Шаблон для розв'язання СЛАР

Вияснимо, як підготувати шаблон під розміри розв'зуваної СЛАР. Для цього виділяємо діапазон F4:F7 (правий стовпець шаблону) і методом перетягування, встановивши курсор мишки на маркер виділеної області (чорний квадратик у правому нижньому куті) таким чином, щоб він перетворився у тоненький знак «+», а потім, утримуючи ліву клавішу мишки (не відпускаючи ії), протягуємо вправо на стільки стовпчиків, щоб кількість змінних СЛАР відповідала кількості змінних на екрані. Потім виділяємо нижній рядочок розширеної нижньої таблиці і протягуємо виділену область вниз настільки, щоб кількість рівнянь СЛАР співпадала із кількістю рівнянь на екрані (див. рис. 2). 


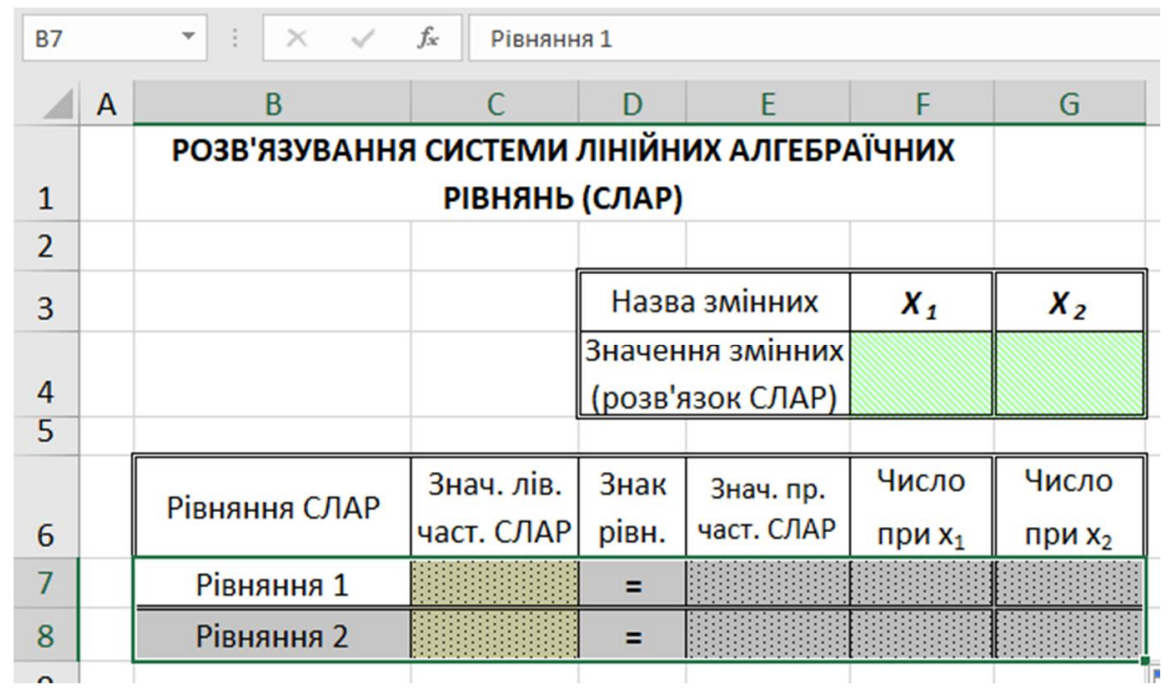

Рис. 2. Адаптований шаблон для розв'язування СЛАР

Приступимо до заповнення створеного шаблону даними розв'язуваної СЛАР. Сьомий рядочок шаблону заповнюємо даними першого рівняння задачі (1): у клітинці E7 набираємо значення правої частини рівняння (число 28), у клітинці F7 - число при $x_{1}$, а у клітинці G7 - коефріцієнт при другій змінній $x_{2}$ (число 2) і так далі, доки не введемо усі коефріцієнти лівої частини першого рівняння, якщо порядок системи більший 2-х.

Аналогічно заповнюємо даними решти рівнянь наступні рядочки нашого шаблону (рис. 3).

\begin{tabular}{|c|c|c|c|c|c|c|c|c|}
\hline E12 & & 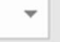 & $\vdots \quad \times \quad \checkmark$ & $f_{x}$ & & & & \\
\hline$\Delta$ & A & & B & $\mathrm{C}$ & D & $\mathrm{E}$ & $\mathrm{F}$ & G \\
\hline 1 & & \multicolumn{6}{|c|}{$\begin{array}{l}\text { РОЗВ'ЯЗУВАННЯ СИСТЕМИ ЛІНІЙНИХ АЛГЕБРАЇЧНИХ } \\
\text { РІВНЯНЬ (СЛАР) }\end{array}$} & \\
\hline \multicolumn{9}{|c|}{ 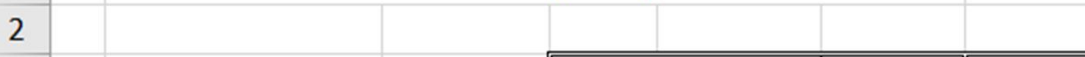 } \\
\hline 3 & & & & & \multicolumn{2}{|c|}{ Назва змінних } & $x_{1}$ & $x_{2}$ \\
\hline 4 & & & & & \multicolumn{2}{|c|}{\begin{tabular}{|r|}
$\begin{array}{r}\text { Значення змінних } \\
\text { (розв'язок СЛАР) }\end{array}$ \\
\end{tabular}} & & \\
\hline \multicolumn{9}{|c|}{ ז } \\
\hline 6 & & Рiвr & Няння СЛАР & $\begin{array}{c}\text { Знач. лів. } \\
\text { част. СЛАР } \\
\end{array}$ & $\begin{array}{l}\text { Знак } \\
\text { рівн. }\end{array}$ & $\begin{array}{c}\text { Знач. пр. } \\
\text { част. СЛАР }\end{array}$ & $\begin{array}{l}\text { Число } \\
\text { при } x_{1}\end{array}$ & $\begin{array}{l}\text { Число } \\
\text { при } x_{2}\end{array}$ \\
\hline 7 & & & Оівняння 1 & & $=$ & 28 & 11 & 1 \\
\hline 8 & & & Оівняння 2 & & $=$ & 0 & 3 & 1 \\
\hline
\end{tabular}

Рис. 3. Заповнення даних в шаблоні СЛАР

У клітинках С7 та С8 потрібно запрограмувати обчислення лівих частин розв'язуваної СЛАР, які у кожному рівнянні $€$ сумою добутків значень змінних (невідомих) на коефіцієнти (числа) при цих невідомих.

Для цього скористаємося вбудованою функцією електронних таблиць СУММПРОИЗВ (сума добутків або російською «сумма произведений»).

Щоб все це реалізувати, активуємо клітинку С7 (наводимо на неї курсор і натискаємо ліву клавішу мишки), вводимо «=» (це означає, що вводиться фрормула) і натискаємо зліва від рядочка формул кнопку вибору функції з позначкою $f_{x}$ (рис. 4). 


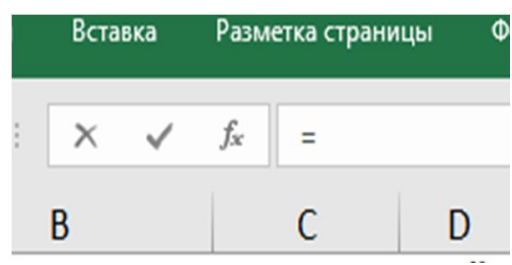

Рис. 4. Розташування кнопки для вставлення функції

У вікні, яке відкрилося (рис. 5), знаходимо потрібну функцію, виділяємо її і натискаємо ОК.

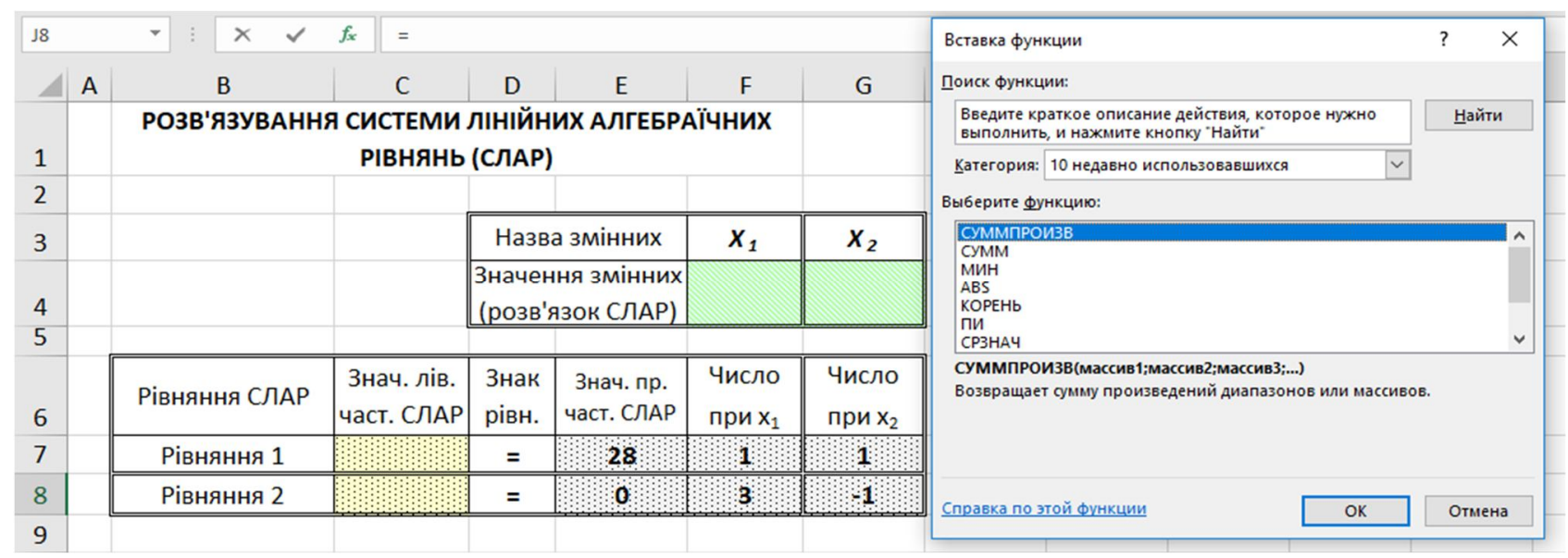

Рис. 5. Вікно вибору функції

Для введення інформації у вікні вибраної функції в активному полі «Массив 1» у четвертому рядку виділяємо клітинки значення змінних для всіх невідомих СЛАР (у активному полі відобразиться діапазон цих виділених клітинок) і обов'язково натискаємо функціональну клавішу F4 (переходимо до абсолютної адресації, щоб під час копіювання цієї формули для наступних рівнянь вона була коректною для них). Потім активуємо поле «Массив 2» і виділяємо клітинки усіх коефіцієнтів лівої частини першого рівняння (діапазон виділених клітинок також відобразиться в активному полі). Зазначимо, що після цього не натискаємо функціональну клавішу F4 (рис. 6). Натискання кнопки ОК завершує введення формули у клітинці С7.

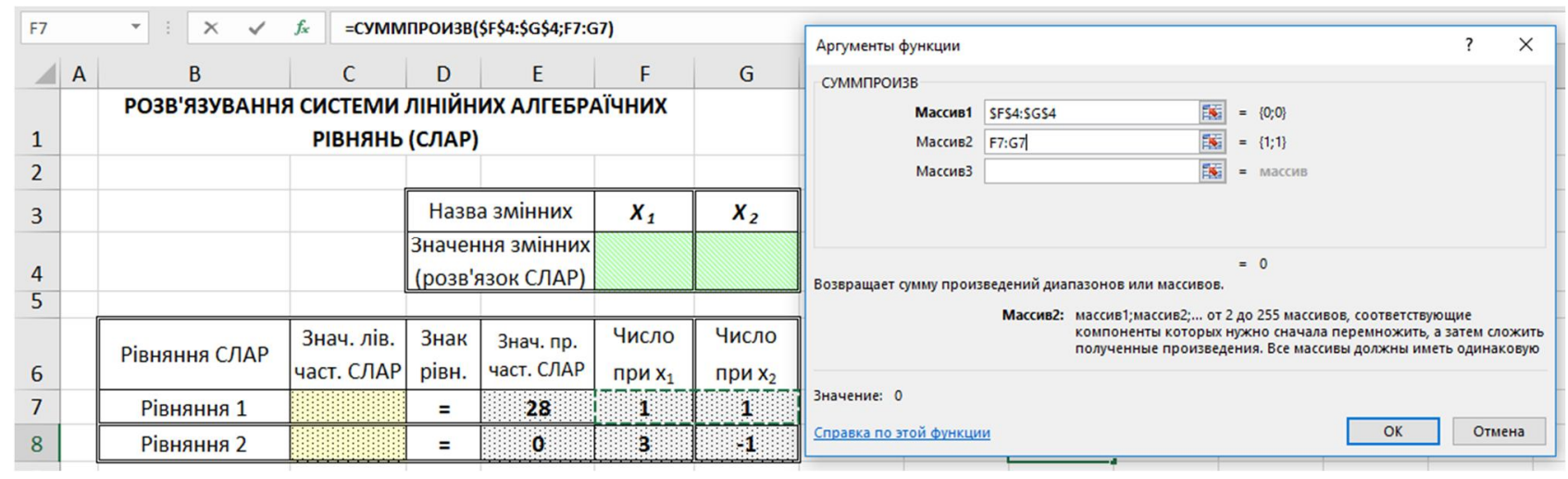

Рис. 6. Програмування обчислення лівої частини першого рівняння СЛАР

Клітинка С7 залишається активною і в ній відобразиться результат щойно введеної функції (число нуль). Встановлюємо курсор Excel на маркер активної клітинки С7 і методом протягування копіюємо формулу з С7 для всіх наступних рівнянь розв'язуваної СЛАР. Після цього у клітинці С8 також буде число нуль. 
Таким чином, СЛАР задачі (1), крім останніх двох нерівностей, відображена в Excel (на рис. 7 вона показана в режимі відображення формул).

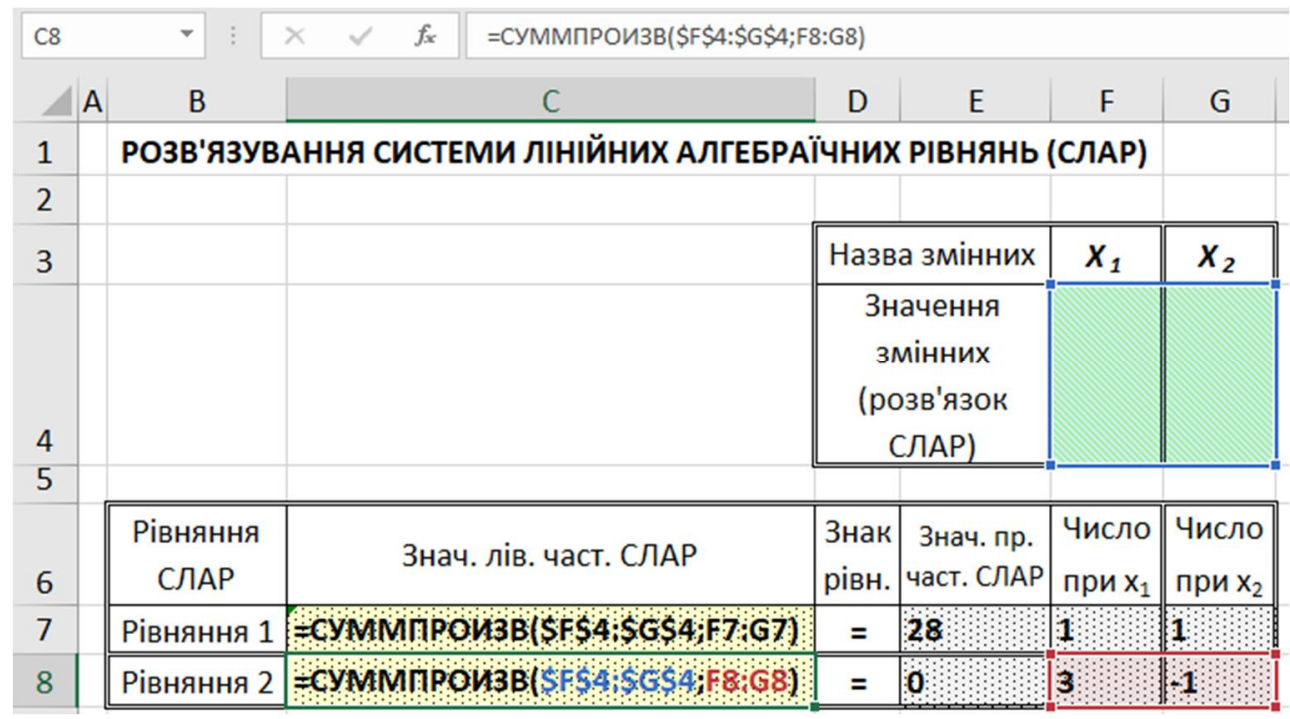

Рис. 7. Режим відображення формул СЛАР

Для запуску надбудови Пошук розв'язку виконаємо команди: у рядку меню заходимо в Дані, у групі Аналіз вибираємо Пошук розв'язку (якщо Пошук розв'язку відсутній, то активуємо його послідовністю дій Файл => Параметри => Надбудови).

Приступимо (див. рис. 8) до заповнення відкритого вікна Параметри пошуку розв'язку (зверху вниз). У першому полі вікна інформація відсутня, а перемикач другого поля може бути будь-яким. Активуємо поле Змінюючи клітинки змінних і виділяємо усі клітинки четвертого рядочка, починаючи 3 клітинки F4 для всіх змінних СЛАР (координати виділеного діапазона автоматично внесуться у активне поле).

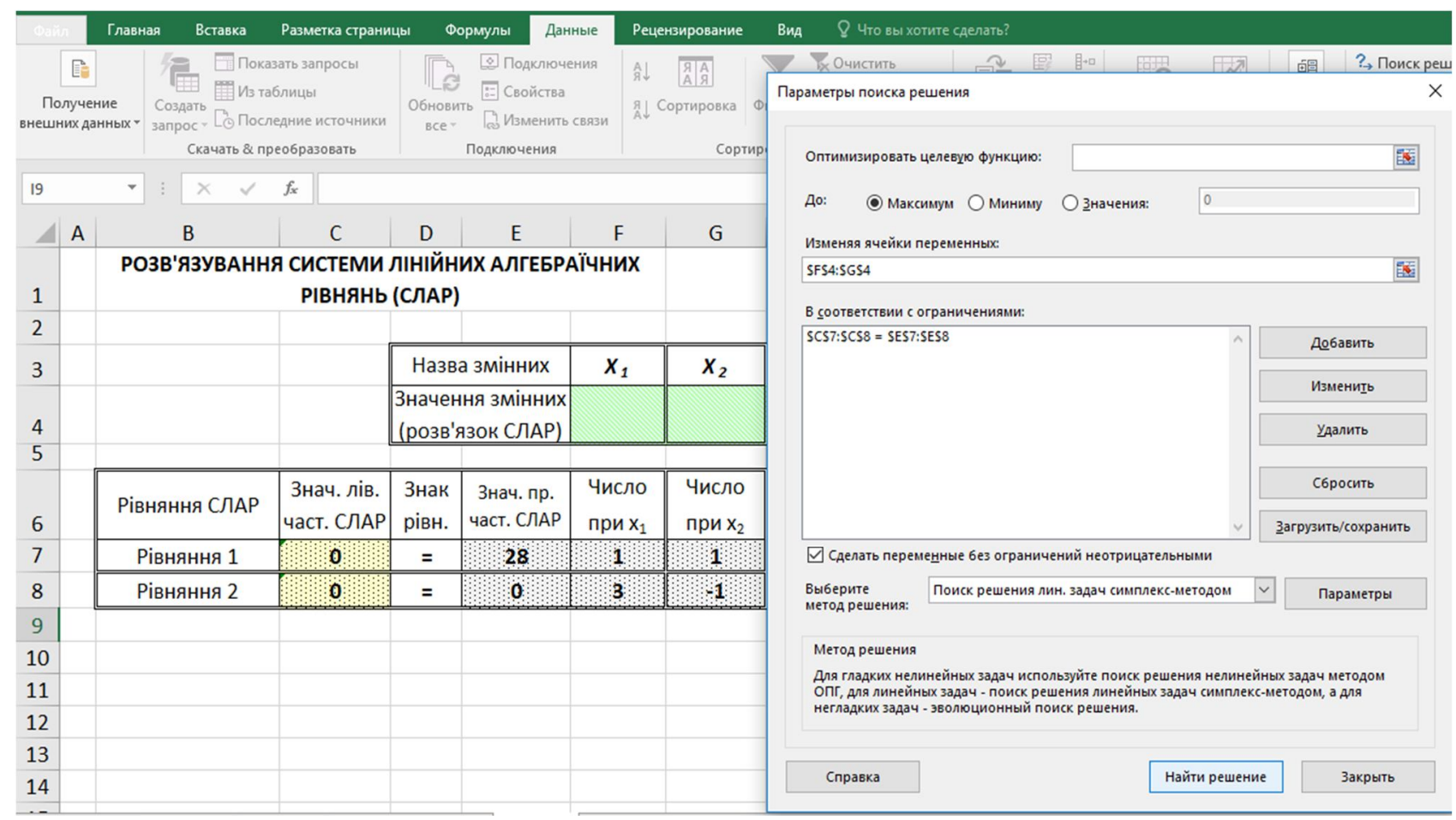

Рис. 8. Заповнення вікна надбудови Пошук розв'язку 
Для заповнення наступного поля натискаємо кнопку Додати (Добавить). Активуємо перше зліва поле відкритого вікна і виділяємо у стовпчику С клітинки, починаючи з сьомого рядочка для всіх рівнянь системи, потім відкриваємо список середнього поля і вибираємо знак «=». Активувавши третє поле, виділяємо у стовпчику Е клітинки, починаючи з сьомого рядочка для всіх рівнянь системи (див. рис. 9), та натисканням кнопки ОК завершуємо введення інформації у полі обмежень.

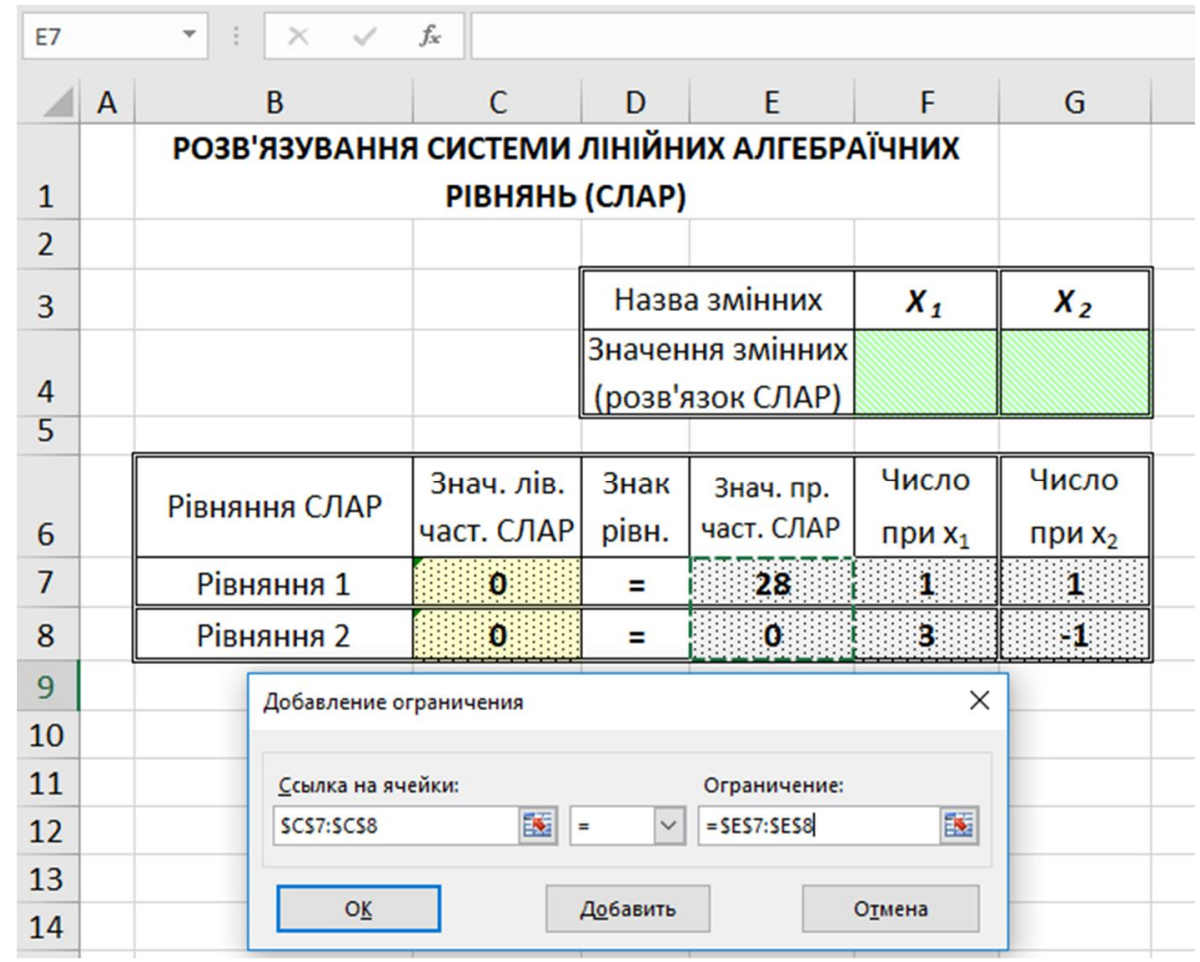

Рис. 9. Задання СЛАР для надбудови Пошуку розв'язків

Якщо розв'язки СЛАР повинні бути невід'ємними (останні дві нерівності в (1)), то ставимо відмітку біля інформації про це, а якщо розв'язки СЛАР можуть бути від'ємними, то відмітка повинна бути відсутня. В наступному полі вибираємо сиплекс метод розв'язання і натискаємо кнопку Знайти розв'язок. Завершивши роботу, програма підтверджує, що розв'язок знайдено і відображає його у четвертому рядочку таблиці, або повідомляє, що розв'язок не знайдено (див. рис. 10). Натискання кнопки ОК закриває це діалогове вікно.

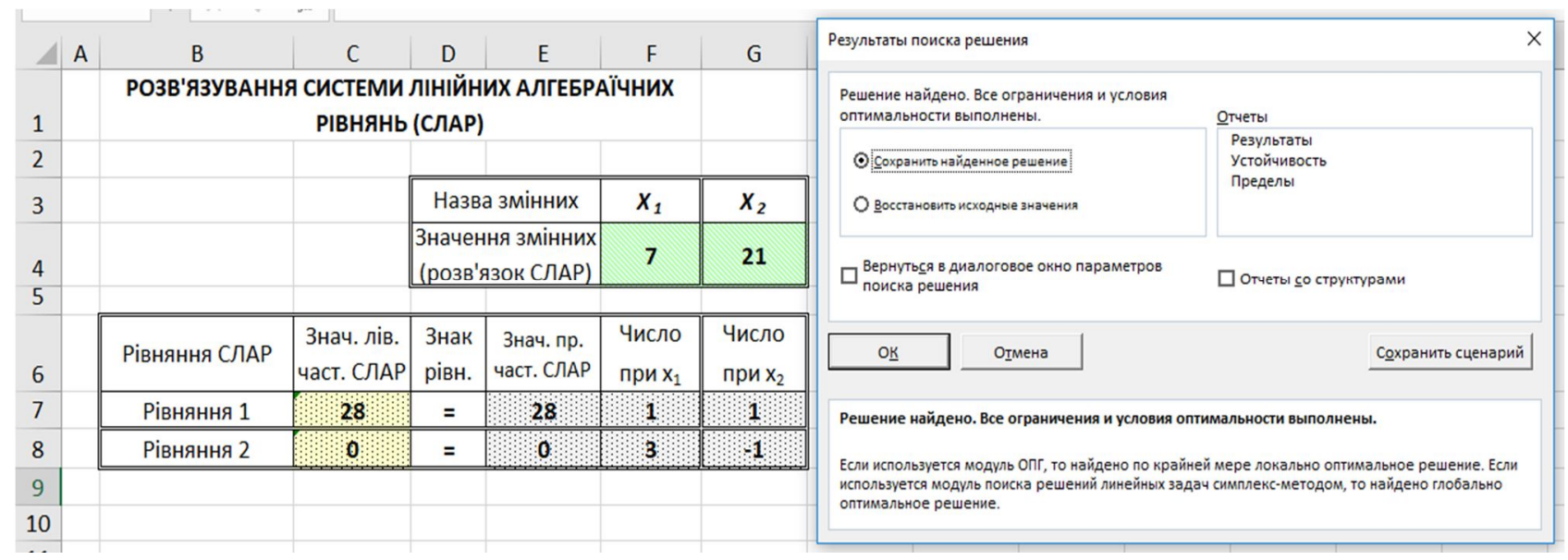

Рис. 10. Діалогове вікно про результати обчислень надбудови Пошук розв'язку 
Висновок. 3 одержаного розв'язку випливає, що для отримання 28 кілограмів нового сплаву 3 рівним вмістом міді й цинку, треба взяти 7 кілограмів першого сплаву та 21 кілограм другого.

Задача 2. Обчисліть масу хлоридної кислоти з масовою часткою гідроген хлориду 20\% і масу хлоридної кислоти з масовою часткою гідроген хлориду 30\%, необхідних для виготовлення 400 г кислоти з масовою часткою гідроген хлориду 25\%. [8]

Побудуємо математичну модель задачі 2. Домовимося хлоридну кислоту з масовою часткою гідроген хлориду: 20\% називати кислота 20; 30\% - кислота 30; 25\% - кислота 25. Позначимо масу кислоти 20, яка буде використана для одержання кислоти 25 через $x_{1}\left(\right.$ (2), а масу кислоти 30 - через $x_{2}$ (2), тоді, за умовою задачі, їхня сума повинна дорівнювати 400 2, тобто одержимо рівняння $x_{1}+x_{2}=400$, а для маси гідроген хлориду справедлива рівність $-0.2 \cdot x_{1}+0.3 \cdot x_{2}=0.25 \cdot 400$ або $0.2 \cdot x_{1}+0.3 \cdot x_{2}=100$. Оскільки наші рівняння повинні виконуватися одночасно, то математична модель задачі 2 матиме вигляд (2), тобто є СЛАР з невід'ємними розв'язками. Задачу (2) розв'язуємо на тому ж аркуші електронних таблиць Microsoft Excel, що і задачу (1), але з даними задачі (2) (див. рис. 11).

$$
\left\{\begin{array}{c}
x_{1}+x_{2}=400 \\
0.2 \cdot x_{1}+0.3 \cdot x_{2}=100 \\
x_{1} \geq 0, x_{2} \geq 0
\end{array}\right.
$$

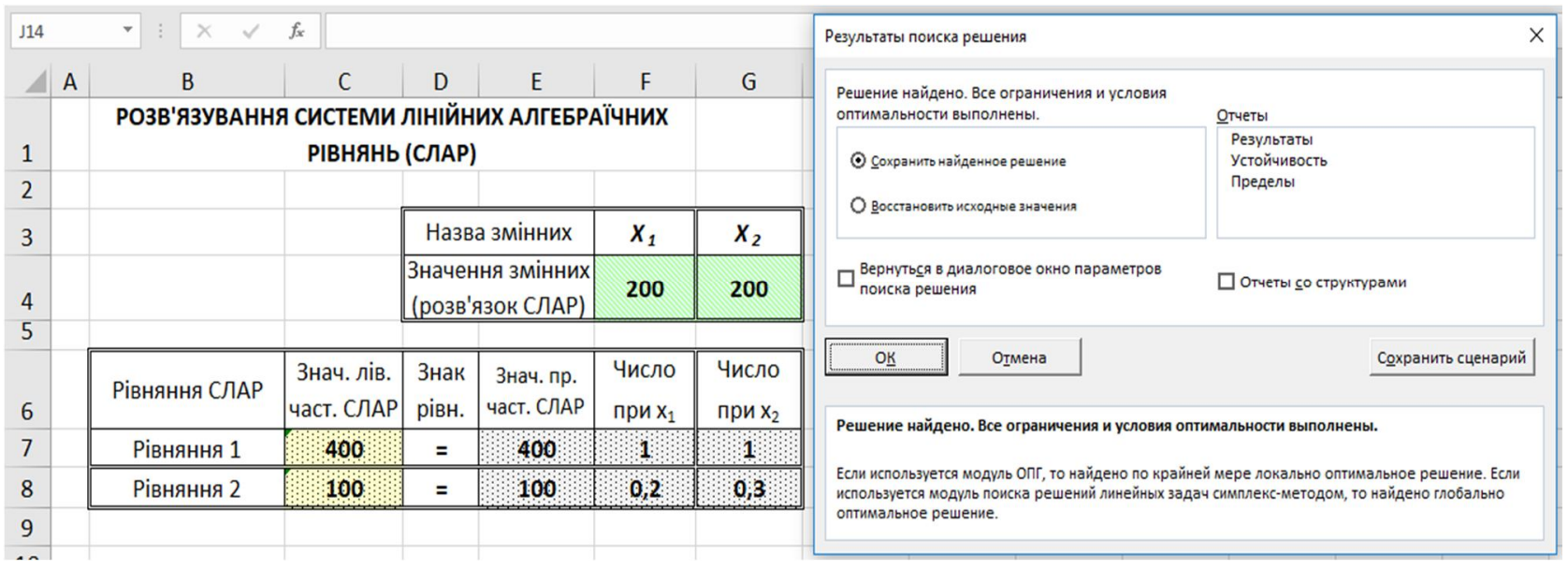

Рис. 11. Розв'язок задачі 2

Висновок. Необхідно взяти 200 г хлоридної кислоти 3 масовою часткою гідроген хлориду 20\% і 200 г хлоридної кислоти 3 масовою часткою гідроген хлориду 30\% для виготовлення 400 г кислоти 3 масовою часткою гідроген хлориду $25 \%$.

Задачі, пов'язані із визначення масової частки компонента у суміші, сплаві чи розчині можуть доповнюватися економічною складовою і, таким чином, сприяти реалізації наскрізної змістової лінії «Підприємливість та фрінансова грамотність», яка забезпечить краще розуміння молоддю практичних аспектів фінансових питань, та формуванню ще однієї ключової компетентності НУШ - ініціативності і підприємливості. Зазначимо, що вищезазначена компетентність передбачає, зокрема, формування «уміння генерувати нові ідеї й ініціативи та втілювати їх у життя..., раціонально вести себе як споживач, ... приймати доцільні рішення у сфері зайнятості, фінансів тощо», а отже розв'язування подібних задач у рамках вивчення хімії, математики та інформатики у З3СО могло б посприяти їі формуванню. Навчальним ресурсом для формування ініціативності та підприємливості, як однієї 3 ключових компетентностей, у програмі з математики зазначено саме задачі підприємницького змісту (наприклад оптимізаційні задачі). 
Задача 3. У заводській лабораторії створюється антисрикційний сплав (олов'янистий бабіт), який має містити: олова -25\%, сурми -15\% , свинцю -60\%. Є п'ять сплавів, дані про які наведено в таблиці 1.

Табл. 1. Склад та вартість сплавів

\begin{tabular}{|l|l|l|l|l|l|}
\hline \multirow{2}{*}{ Елементи } & \multicolumn{5}{|c|}{ Сплави } \\
\cline { 2 - 7 } & $\mathbf{1}$ & $\mathbf{2}$ & $\mathbf{3}$ & $\mathbf{4}$ & $\mathbf{5}$ \\
\hline Олово (\%) & 25 & 20 & 30 & 20 & 25 \\
\hline Сурма (\%) & 25 & 18 & 15 & 14 & 20 \\
\hline Свинець (\%) & 50 & 62 & 55 & 66 & 55 \\
\hline Ціна (у.г.о./кг) & 6 & 5,2 & 7 & 7,7 & 6,7 \\
\hline
\end{tabular}

Розрахувати маси сплавів кожного виду, необхідних для виготовлення 1кг олов'янистого бабіту найменшої вартості.

Створимо математичну модель задачі 3. Для цього позначимо масу першого сплаву, яку використаємо для створення нового сплаву, через $x_{1}(2)$, другого - через $x_{2}(2), \ldots$, п'ятого - $x_{5}(2)$, Тоді їх сума повинна дорівнювати 'масі нового сплаву (суміші), а це означає, що повинна виконуватися рівність $x_{1}+x_{2}+x_{3}+x_{4}+x_{5}=1000$. Визначимо масу олова у суміші, яка $€$ сумою мас олова, що міститься у кожній частці всіх п'яти сплавів (таблиця 1), з яких утворено 1 ка суміші:

$$
0.25 \cdot x_{1}+0.2 \cdot x_{2}+0.3 \cdot x_{3}+0.2 \cdot x_{4}+0.25 \cdot x_{5}=0.25 \cdot 1000=250 .
$$

Аналогічно для сурми:

$$
0.25 \cdot x_{1}+0.18 \cdot x_{2}+0.15 \cdot x_{3}+0.14 \cdot x_{4}+0.2 \cdot x_{5}=0.15 \cdot 1000=150,
$$

і для свинцю:

$$
0.5 \cdot x_{1}+0.62 \cdot x_{2}+0.55 \cdot x_{3}+0.66 \cdot x_{4}+0.55 \cdot x_{5}=0.60 \cdot 1000=600 .
$$

Оскільки всі чотири, одержані нами, рівняння повинні виконуватися одночасно, то маємо СЛАР, у якій $є$ п'ять змінних та чотири рівняння. Математично доведено, що така СЛАР має безліч розв'язків, а не один, як дві попередні. Це означає, що є не єдиний варіант одержання 1 ка олов'янистого бабіту, але кожний з них матиме різну вартість. Тому виберемо з усіх можливих варіантів такий, для якого вартість 1 ке антифрикційного сплаву буде найменшою, тобто

$$
V\left(x_{1}, \ldots x_{5}\right)=0.006 \cdot x_{1}+0.0052 \cdot x_{2}+0.007 x_{3}+0.0077 \cdot x_{4}+0.0067 \cdot x_{5} \rightarrow \min
$$

Таким чином, математична модель задачі 3 матиме вигляд:

$$
\begin{gathered}
V\left(x_{1}, \ldots x_{5}\right)=0.006 \cdot x_{1}+0.0052 \cdot x_{2}+0.007 x_{3}+0.0077 \cdot x_{4}+0.0067 \cdot x_{5} \rightarrow \min \\
x_{1}+x_{2}+x_{3}+x_{4}+x_{5}=1000, \\
0.25 x_{1}+0.2 x_{2}+0.3 x_{3}+0.2 x_{4}+0.25 x_{5}=250, \\
0.25 x_{1}+0.18 x_{2}+0.15 x_{3}+0.14 x_{4}+0.2 x_{5}=150, \\
0.5 x_{1}+0.62 x_{2}+0.55 x_{3}+0.66 x_{4}+0.55 x_{5}=600, \\
x_{1} \geq 0, x_{2} \geq 0, x_{3} \geq 0, x_{4} \geq 0, x_{5} \geq 0 .
\end{gathered}
$$

Математична задача (3)-(4) є задачею лінійного програмування:

(3) - цільова функція (обчислює вартість результуючого сплаву);

(4) - система обмежень (умови для досягнення мети цільової функції).

Цю задачу також розв'яжемо за допомогою надбудови Пошук розв'язку.

Електронний шаблон, який використовували для розв'язання попередніх задач, підганяємо під розміри нашої задачі (див. рис.12) і додаємо табличку для цільової функції (3) (середня табличка на рис.12) [9]. 


\begin{tabular}{|c|c|c|c|c|c|c|c|c|c|}
\hline B7 & 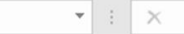 & $\checkmark f_{x}$ & $=$ =УММПР & оизв(Е4:14;E7:17 & & & & & \\
\hline$\Delta$ & A & $\mathrm{B}$ & $\mathrm{C}$ & $\mathrm{D}$ & E & $\mathrm{F}$ & G & $\mathrm{H}$ & 1 \\
\hline 1 & \multicolumn{9}{|c|}{ РОЗВ'ЯЗУВАННЯ ЗАДАЧІ ЛІНІЙНОГО ПРОГРАМУВАННЯ } \\
\hline 2 & & & & & & & & & \\
\hline 3 & & \multicolumn{3}{|c|}{ Назва змінних } & $x_{1}$ & $x_{2}$ & $x_{3}$ & $x_{4}$ & $x_{5}$ \\
\hline 4 & & \multicolumn{3}{|c|}{$\begin{array}{c}\text { Значення змінних } \\
\text { (розв'язок) }\end{array}$} & & & & & \\
\hline \multicolumn{10}{|c|}{ " } \\
\hline 6 & & $\begin{array}{c}\text { Знач. ціл. } \\
\text { функції }\end{array}$ & $\begin{array}{r}\text { Мета } \\
\phi\end{array}$ & $\begin{array}{l}\text { цільової } \\
\text { ункції }\end{array}$ & $\begin{array}{l}\text { Число } \\
\text { при } \mathrm{x}_{1}\end{array}$ & $\begin{array}{l}\text { Число } \\
\text { при } x_{2} \\
\end{array}$ & $\begin{array}{l}\text { Число } \\
\text { при } x_{3}\end{array}$ & $\begin{array}{l}\text { Число } \\
\text { при } \mathrm{x}_{4} \\
\end{array}$ & $\begin{array}{l}\text { Число } \\
\text { при } x_{5}\end{array}$ \\
\hline 7 & & 0 & найме & нше ( $\mathrm{min})$ & 0,006 & 0,0052 & 0,007 & 0,0077 & 0,0067 \\
\hline \multicolumn{10}{|l|}{8} \\
\hline 9 & Назва обмеження & $\begin{array}{l}\text { Знач. лів. } \\
\text { част. обм. }\end{array}$ & $\begin{array}{l}\text { Знак } \\
\text { обм. }\end{array}$ & $\begin{array}{l}\text { Знач. пр. } \\
\text { част. обм. }\end{array}$ & $\begin{array}{l}\text { Число } \\
\text { при } x_{1}\end{array}$ & $\begin{array}{l}\text { Число } \\
\text { при } x_{2}\end{array}$ & $\begin{array}{l}\text { Число } \\
\text { при } x_{3}\end{array}$ & $\begin{array}{l}\text { Число } \\
\text { при } x_{4} \\
\end{array}$ & $\begin{array}{l}\text { Число } \\
\text { при } x_{5}\end{array}$ \\
\hline 10 & Вага нового спл. & 0 & $=$ & 1000 & 1 & 1 & 1 & 1 & 1 \\
\hline 11 & К-ть олова & 0 & $=$ & 250 & 0,25 & 0,2 & 0,3 & 0,2 & 0,25 \\
\hline 12 & К-ть сурми & 0 & $=$ & 150 & 0,25 & 0,18 & 0,15 & 0,14 & 0,2 \\
\hline 13 & К-Ть свинцю & 0 & $=$ & 600 & 0,5 & 0,62 & 0,55 & 0,66 & 0,55 \\
\hline
\end{tabular}

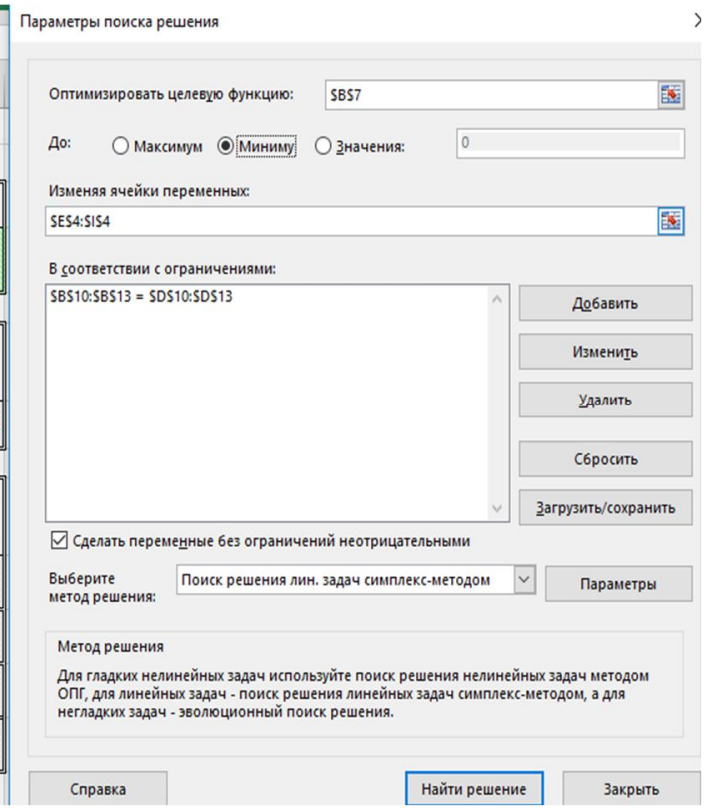

Рис. 12. Задання даних для розв'язування задачі лінійного програмування

У клітинку В7 вводимо формулу =СУММПРОИЗВ(E4:14;E7:17), а, починаючи з клітинки E7, коефріцієнти цільової фрункції (3). Активуємо клітинку В7, запускаємо надбудову Пошук розв'язку і заповнюємо даними задачі вікно Параметри пошук розв'язку, як показано на рис.11 (адреса клітинки обчислення цільової функції у верхньому полі введеться автоматично, нижче вказуємо мету цільової функції, вибравши перемикач Мінімум, а задання решти даних читачеві уже знайомо). Натиснувши кнопку Знайти розв'язок, побачимо його у четвертому рядочку та клітинці В7 (рис.13).

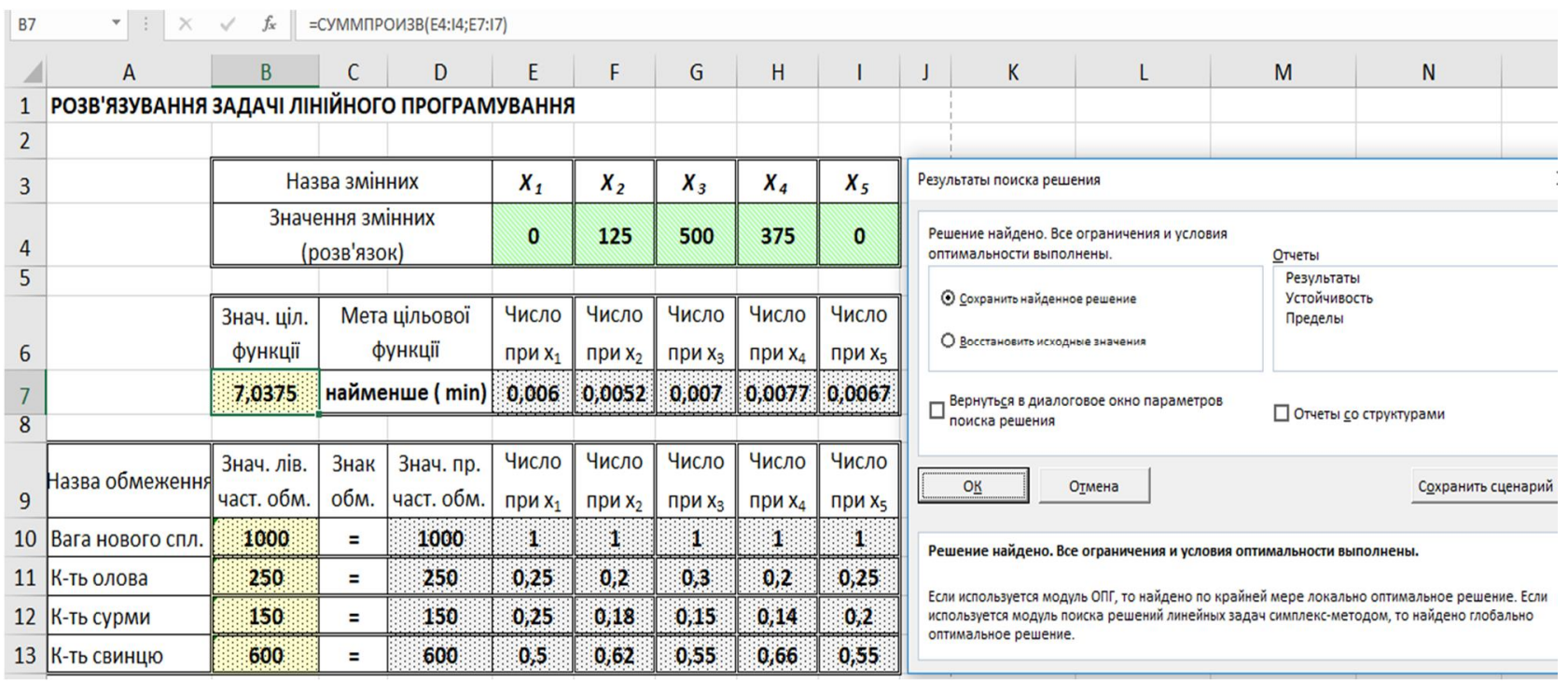

Рис. 13. Розв'язок задачі лінійного програмування

Висновок. Для одержання 1 кг антифрикційного сплаву вартістю 7,04 у.г.о. треба взяти 125 г другого сплаву, 500 г - третього і 375 г - четвертого, а перший та п'ятий сплави не використовувати.

Зауваження. Щоб читач переконався, що СЛАР (4) має більше одного розв'язку, наведемо ще два інших її розв'язки у таблиці 2 та вартості 1 ке антифрикційних сплавів, виготовлених за даними цих розв'язків. 
Табл. 2. Приклади різних варіантів одержання антифрикційних сплавів

\begin{tabular}{|l|c|c|c|c|c|c|}
\hline \multirow{2}{*}{ Розв'язок } & \multicolumn{5}{|c|}{ Сплави (2) } & Вартість \\
\cline { 2 - 7 } & $X_{1}$ & $X_{2}$ & $X_{3}$ & $X_{4}$ & $X_{5}$ & (у.2.0.) \\
\hline Перший & 21,583 & 68,345 & 489,209 & 420,863 & 0,000 & 7,15 \\
\hline Другий & 8,333 & 0,000 & 458,333 & 458,333 & 75,000 & 7,29 \\
\hline Оптимальний & $\mathbf{0}$ & $\mathbf{1 2 5}$ & $\mathbf{5 0 0}$ & $\mathbf{3 7 5}$ & $\mathbf{0}$ & $\mathbf{7 , 0 4}$ \\
\hline
\end{tabular}

\section{IV Обговорення}

Проблема інтеграції навчальних дисциплін та впровадження у їх викладання елементів комп'ютерного моделювання останніми роками порушується багатьма українськими [10-13] та зарубіжними вченими [14-21], оскільки у світі, що швидко змінюється, суспільство постійно стикається із необхідністю вирішенням переважно не вузькоспеціалізованих, а комплексних та мультидисциплінарних проблем, а отже випускник З3СО має бути максимально готовий до успішної самореалізації в таких умовах. Зокрема ірландські вчені Г. Уолше та ін. розглядають питання інтеграції елементів математики в предмет Science (Природничі науки), через розробку авторської моделі навчального плану [14], проте їх розробка не передбачає інтеграції Science в математику і взагалі не розглядає інтеграції інформатики в інші предмети Ірландські науковці М.Н. Ріордейн та ін. вивчали питання взаємної інтеграції математики та Science, проте також оминули увагою інформатику [18].

Багато зарубіжних науковців займається питаннями інтеграції математики та природничих дисциплін [14,17-19] та впровадженням “комп'ютаційного мислення" або елементів моделювання у викладання природничих предметів [15,16,20]. Зокрема, Д. Вейнтроп та ін. [15] пропонують впроваджувати у математику та Science елементи «комп'ютаційного мислення» (обчислювальне мислення, computational thinking) з метою підготовки учнів до подальшої кар'єри, пов'язаної 3 математикою чи природничими науками, оскільки всі галузі науки стають все більше комп'ютеризованими. Д.Ф. Берлін та А.Л. Уайт запропонували авторську модель інтегрованого викладання Science та математики [17]. Л. Малоне, Джексон та ін.. займалися питаннями впровадження елементів моделювання, зокрема і засобами табличного процесора Excel, у викладання деяких природничих дисциплін у старшій школі, зокрема біології [16] та фізики [20, 21], проте навчальний процес з хімії оминули увагою і не піднімали питання впровадження елементів природничих наук у викладання інформатики. А. Кірей здійснив обширний аналіз різних моделей інтеграції Science та математики та запропонував свою Збалансовану модель, підкреслюючи важливість балансу в процесі інтеграції [19].

Розв'язанням у загальному вигляді проблеми, подібної до піднятої нами, а саме, вивченням питання використання комп'ютерного моделювання для формування компетентностей учнів 3 природничо-математичних предметів, займалася український науковець С.Г. Литвинова, акцентуючи увагу на необхідності підвищення фахового рівня підготовки майбутніх вчителів природничоматематичних дисциплін та зазначаючи, що комп'ютерне моделювання сприяє розвитку в учнів інтелектуальних умінь, глибокому розумінню процесів, що моделюються; формуванню дослідницьких умінь, поглибленню знань і вмінь з інформатики, фрізичних, хімічних, біологічних та математичних дисциплін тощо [11]. Вітчизняні педагоги також вивчали застосування математичного моделювання для розвитку математичних компетентностей та уроках математики [13], для активізації пізнавальної діяльності в навчальному процесі з фізики [12].

Зазначимо, що електронні таблиці Excel використовуються не тільки в навчальному процесі, але і для проведення обчислень у наукових дослідженнях [22-24]. Там, наприклад, пропонується розв'язувати системи лінійних алгебраїчних рівнянь (СЛАР) з використанням оберненої матриці, але такий підхід неприйнятний у навчальному процесі 33СО, оскільки програмою не передбачено вивчення учнями матричного числення. Запропонований у публікації алгоритм, як показує практичний досвід, $є$ зрозумілим для учнів способом розв'язання СЛАР в Excel. 
Таким чином, незважаючи на значну увагу науковців до питання інтеграції природничих дисциплін та математики, а також до проблеми використання елементів математичного і комп'ютерного моделювання у навчальному процесі з математики та природничих дисциплін, в цій галузі залишається ще багато не дослідженого. Новизна запропонованого нами підходу полягає в тому, що пропонується використовувати елементи математичного моделювання у середовищі табличного процесора Excel, які $€$ зрозумілими для учнів 9-го класу, не лише на уроках інформатики, а і в процесі викладання хімії та математики, сприяючи комплексному формуванню ключових компетентностей, реалізації змістових ліній Нової української школи та як складову актуального сьогодні напряму STEM-освіти. Також вказаний підхід полегшує розв'язання прикладних задач, які зводяться до систем лінійних алгебраїчних рівнянь вищих порядків.

\section{V Висновки}

Отож, у статті продемонстровано, що математичну, інформаційно-цифрову компетентності, компетентності у природничих науках і технологіях та ініціативність і підприємливість, як ключові компетентності НУШ, можна комплексно розвивати через міжпредметну інтеграцію шляхом створення і розв'язування простих математичних моделей задач, пов'язаних із поняттям масової частки розчиненої речовини у розчині, масової частки одного з компонентів у суміші твердих, рідких або газоподібних речовин чи масової частки компонента у сплаві за допомогою табличного процесора MS Excel під час вивчення відповідних тем з хімії, математики та/або інформатики у 9-х класах 33СО.

\section{Бібліографічні посилання}

1. Онопрієнко О. Концепція нової української школи як ідейна основа модернізації освітнього середовища / Модернізація освітнього середовища: проблеми та перспективи: матеріали Другої Міжнародної науково-практичної конфреренції (5-6 жовтня 2017 р., м. Умань) / FOLIA COMENIANA: Вісник Польсько-української науководослідницької лабораторії психодидактики імені Я. А. Коменського. Умань: ВПЦ «Візаві», 2017. С. 27-31.

2. Краснобокий Ю. М., Ткаченко І. А. Інтеграція природничо-наукових дисциплін у світлі компетентнісної парадигми освіти / Теорія та методика навчання фундаментальних дисциплін у вищій школі: збірник наукових праць. Випуск VIII. Кривий Ріг: Видавничий відділ КМІ, 2013. С. 83-89.

3. Концепція Нової української школи. URL: https://www.kmu.gov.ua/storage/app/media/reforms/ukrainska-shkolacompressed.pdf (дата звернення 05.09.2019).

4. Хімія. 7-9 клас. Навчальна програма для загальноосвітніх навчальних закладів затверджена наказом МОН від 07.06.2017 № 804. URL: https:/mon.gov.ua/storage/app/media/zagalna\%20serednya/programy-5-9-klas/onovlennya-122017/10-ximiya-7-9. doc (дата звернення 05.09.2019).

5. Математика. 5-9 клас. Навчальна програма для загальноосвітніх навчальних закладів затверджена наказом МОH від 07.06.2017 № 804. URL: https://mon.gov.ua/storage/app/media/zagalna\%20serednya/programy-5-9-klas/onovlennya12-2017/5-programa-z-matematiki.docx (дата звернення 05.09.2019).

6. Інформатика. 5-9 клас. Навчальна програма для загальноосвітніх навчальних закладів затверджена наказом МОН від 07.06.2017 № 804. URL: https://mon.gov.ua/storage/app/media/zagalna\%20serednya/programy-5-9-klas/onovlennya12-2017/programa-informatika-5-9-traven-2015.pdf (дата звернення 05.09.2019).

7. Мерзляк А. Г., Полонський В.Б., Якір М. С. Алгебра для загальноосвітніх навчальних закладів з поглибленим вивченням математики : підруч. для 9 кл. загальноосв. навч. закл. Х. : Гімназія, 2017. 416 с.

8. Я Ярошенко О. Г. Хімія : підруч. для 9 кл. загальноосвіт. навч. закладів. К.: УОВЦ «Оріон», 2017. 224 с.

9. Семчук А. Р., Денисенко В. І., Готинчан І. 3. Економіко-математичні методи і моделі: оптимізаційні задачі : навч.метод. посібник. Вид. 2-е, змінене і доповнене. Чернівці : «Місто», 2018. 176 с.

10. Інтеграція знань з предметів природничо-математичного циклу: проблеми та шляхи їх вирішення: збірник матеріалів інтернет-семінару, частина II ; упорядник Замулко О.І. Черкаси, 2012. 88 с.

11. Литвинова С. Г. Модель використання системи комп'ютерного моделювання для формування компетентностей 3 природничо-математичних предметів / Фізико-математична освіта. 2019. Випуск 1 (19). С. 108-115.

12. Слободяник О. В. Комп'ютерні моделі як засіб активізації пізнавальної діяльності на уроках фізики / Фізикоматематична освіта. 2018. Випуск 4(18). С. 149-153. doi: 10.31110/2413-1571-2018-018-4-025

13. Катериниюк Г. Д. Розвиток математичних компетентностей учнів у процесі формування здатності до математичного моделювання. / Сучасні інформаційні технології та інноваційні методики навчання у підготовці фахівців: методологія, теорія, досвід, проблеми: Зб. наук. пр., Випуск 47. Київ-Вінниця: ТОВ фірма «Планер», 2016. С. 63-67.

14. Walshe G., Johnston J., McClelland G. Integrating Mathematics into Science: Design, Development and Evaluation of a Curriculum Model / Cognitive and Affective Aspects in Science Education Research: Selected Papers from the ESERA 2015 Conference. Dordrecht: Springer. P. 309-321. 
15. Weintrop D., Beheshti E., Horn M., Orton K., Jona K., Trouille L., Wilensky U. Defining computational thinking for mathematics and science classrooms / Journal of Science Education and Technology. 2015. 25(1). P. 127-147. doi: 10.1007/s10956-015-9581-5.

16. Malone K. L., Schunn C. D., Schuchardt A. M. Improving Conceptual Understanding and Representation Skills Through Excel-Based Modeling / Journal of Science Education and Technology. 2018. 27 (1). PP. 30-44. doi: https://doi.org/10.1007/s10956-017-9706-0.

17. Berlin D. F., White A. L. The Berlin-White Integrated Science and Mathematics Model / School Science and Mathematics. 1994. 94(1). PP. 2-4.

18. Ríordáin M. N., Johnston J., Walshe G. Making mathematics and science integration happen: key aspects of practice / International Journal of Mathematical Education in Science and Technology. 2015. 47. PP. 233-255. doi: http://dx.doi.org/10.1080/0020739X.2015.1078001.

19. Kiray S. A. A new model for the integration of science and mathematics: The balance model / Energy Education Science and Technology. Part B: Social and Educational Studies. 2012. 4(3). PP. 1181-1196.

20. Benecka J. Numerical Modelling with Spreadsheets as a Means to Promote STEM to High School Students / Eurasia Journal of Mathematics. Science and Technology Education. 2016. 12(4). PP. 947-964.

21. Jackson J, Dukerich L, Hestenes D. Modeling instruction: an effective model for science education / Sci Educ. 2008. 17(1). PP. 10-17.

22. Вильямс О. EXCEL для учёных, инженеров и студентов. К. : Юниор,1999. 528 с.

23. Васильев А. Н. Научные вычисления в Microsoft Excel. М. : Издательский дом "Вильяме", 2004. 512 c.

24. Уокенбах Д. Microsoft Excel 2010. Библия пользователя. М. : ООО “И.Д.Вильямс", 2013. 912 с.

\section{References}

1. Onopriienko, O. (2017). Kontseptsiia novoi ukrainskoi shkoly yak ideina osnova modernizatsii osvitnoho seredovyshcha. Modernizatsiia osvitnoho seredovyshcha: problemy ta perspektyvy: materialy Druhoi Mizhnarodnoi naukovo-praktychnoi konferentsii, Uman, 5-6 October, 2017, FOLIA COMENIANA: Visnyk Polsko-ukrainskoi naukovo-doslidnytskoi laboratorii psykhodydaktyky imeni Ya. A. Komenskoho, VPTs «Vizavi», Uman, pp. 27-31. [in Ukrainian]

2. Krasnobokyi, Yu. M., Tkachenko, I. A. (2013). Intehratsiia pryrodnycho-naukovykh dystsyplin u svitli kompetentnisnoi paradyhmy osvity. Teoriia ta metodyka navchannia fundamentalnykh dystsyplin u vyshchii shkoli: zbirnyk naukovykh prats. Vypusk VIII, Vydavnychyi viddil KMl, Kryvyi Rih, pp. 83-89. [in Ukrainian]

3. (2016). Kontseptsiia Novoi ukrainskoi shkoly. URL: https://www.kmu.gov.ua/storage/app/media/reforms/ukrainska-shkolacompressed.pdf (accessed 05.09.2019). [in Ukrainian]

4. (2017). Khimiia. 7-9 klas. Navchalna prohrama dlia zahalnoosvitnikh navchalnykh zakladiv zatverdzhena nakazom MON vid 07.06.2017 № 804. URL: https://mon.gov.ua/storage/app/media/zagalna\%20serednya/programy-5-9-klas/onovlennya12-2017/10-ximiya-7-9. doc (accessed 05.09.2019). [in Ukrainian]

5. (2017). Matematyka. 5-9 klas. Navchalna prohrama dlia zahalnoosvitnikh navchalnykh zakladiv zatverdzhena nakazom MON vid 07.06.2017 № 804. URL: https://mon.gov.ua/storage/app/media/zagalna\%20serednya/programy-5-9klas/onovlennya-12-2017/5-programa-z-matematiki.docx (accessed 05.09.2019). [in Ukrainian]

6. (2017). Informatyka. 5-9 klas. Navchalna prohrama dlia zahalnoosvitnikh navchalnykh zakladiv zatverdzhena nakazom MON vid 07.06.2017 № 804. URL: https://mon.gov.ua/storage/app/media/zagalna\%20serednya/programy-5-9klas/onovlennya-12-2017/programa-informatika-5-9-traven-2015.pdf (accessed 05.09.2019). [in Ukrainian]

7. Merzliak, A. H., Polonskyi, V.B., Yakir, M.S. (2017). Alhebra dlia zahalnoosvitnikh navchalnykh zakladiv z pohlyblenym vyvchenniam matematyky: pidruch. dlia 9 kl. zahalnoosv. navch. zakl. Himnaziia, Kharkiv, Ukraine, 416. [in Ukrainian]

8. laroshenko, O. H. (2017). Khimiia: pidruch. dlia 9 kl. zahalnoosvit. navch. zakladiv. UOVTs «Orion», Kyiv, Ukraine, 224. [in Ukrainian]

9. Semchuk, A. R., Denysenko, V. I., Hotynchan, I. Z. (2012). Ekonomiko-matematychni metody i modeli: optymizatsiini zadachi : navch.-metod. posibnyk. «Misto», Chernivtsi, Ukraine, 176. [in Ukrainian]

10. Zamulko, O. I. (Ed.) (2012). Intehratsiia znan z predmetiv pryrodnycho-matematychnoho tsyklu: problemy ta shliakhy yikh vyrishennia : zbirnyk materialiv internet-seminaru, chastyna II. Cherkasy, Ukraine, 88. [in Ukrainian]

11. Lytvynova, S. H. (2019). Model vykorystannia systemy kompiuternoho modeliuvannia dlia formuvannia kompetentnostei z pryrodnycho-matematychnykh predmetiv. Fizyko-matematychna osvita, 1(19), 108-115. [in Ukrainian]

12. Slobodianyk, O. V. (2018). Computer Models In The Research Activity Of Students In Physics. Physical and Mathematical Education, 4(18), 149-153. doi: 10.31110/2413-1571-2018-018-4-025. [in Ukrainian]

13. Katerynyiuk, H. D. (2016). Rozvytok matematychnykh kompetentnostei uchniv u protsesi formuvannia zdatnosti do matematychnoho modeliuvannia. Suchasni informatsiini tekhnolohii ta innovatsiini metodyky navchannia u pidhotovtsi fakhivtsiv: metodolohiia, teoriia, dosvid, problemy: Zb. nauk. pr., 47,63-67. [in Ukrainian]

14. Walshe, G., Johnston, J., McClelland, G. (2015). Integrating Mathematics into Science: Design, Development and Evaluation of a Curriculum Model. Cognitive and Affective Aspects in Science Education Research: Selected Papers from the ESERA 2015 Conference. Springer, Dordrecht, 309-321.

15. Weintrop, D., Beheshti, E., Horn, M., Orton, K., Jona, K., Trouille, L., Wilensky, U. (2016). Defining computational thinking for mathematics and science classrooms. Journal of Science Education and Technology, 2015, 25(1), 127-147. doi: 10.1007/s10956-015-9581-5. 
16. Malone, K. L., Schunn, C. D., Schuchardt, A. M. (2018). Improving Conceptual Understanding and Representation Skills Through Excel-Based Modeling. Journal of Science Education and Technology, 27 (1), 30-44. doi: https://doi.org/10.1007/s10956-017-9706-0.

17. Berlin, D. F., White, A. L. (1994). The Berlin-White Integrated Science and Mathematics Model. School Science and Mathematics, 94(1), 2-4.

18. Ríordáin, M. N., Johnston, J., Walshe, G. (2015). Making mathematics and science integration happen: key aspects of practice. International Journal of Mathematical Education in Science and Technology, 47, 233-255. doi: http://dx.doi.org/10.1080/0020739X.2015.1078001.

19. Kiray, S. A. (2012). A new model for the integration of science and mathematics: The balance model. Energy Education Science and Technology. Part B: Social and Educational Studies, 4(3), 1181-1196.

20. Benecka, J. (2016). Numerical Modelling with Spreadsheets as a Means to Promote STEM to High School Students. Eurasia Journal of Mathematics, Science and Technology Education, 12(4), 947-964.

21. Jackson, J, Dukerich, L, Hestenes, D. (2008). Modeling instruction: an effective model for science education. Sci Educ., $17(1), 10-17$.

22. Vil'yams, O. (1999). EXCEL dlya uchyony`kh, inzhenerov i studentov. Yunior, Kyiv, Ukraine, 528. [in Russian]

23. Vasil'ev, A. N. (2004). Nauchny`e vy’chisleniya v Microsoft Excel. Izdatel’skij dom "Vil'yame", Moscow, Russia, 512. [in Russian]

24. Uokenbakh, D. (2013). Microsoft Excel 2010. Bibliia polzovatelia. OOO “I.D.Viliams”, Moscow, Russia, 912. [in Russian]

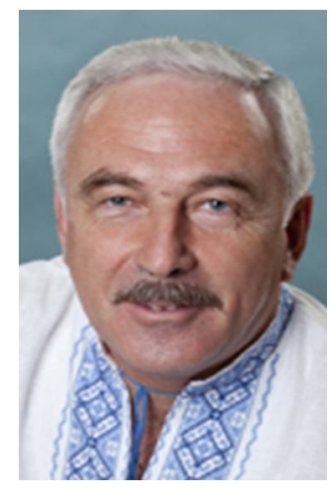

\section{Семчук Аркадій Романович.}

Кандидат фіз.-мат. наук, доцент, доцент кафедри методики викладання природничо-

математичних дисциплін, Інститут післядипломної педагогічної освіти Чернівецької області,

вул. Франка, 20, м. Чернівці, Україна, 58000.

Тел. 0506719889. E-mail: semark@ukr.net

\section{Semchuk Arkadii Romanovych.}

Cand.Sc. in mathematics, Associate Professor, Associate Professor of Department of Natural and Mathematical Subjects Teaching Methodology, Chernivtsi In-Service Teacher Training Institute, Franko str., 20, Chernivtsi, Ukraine, 58000.

Tel. 0506719886. E-mail: semark@ukr.net

ORCID: https://orcid.org/0000-0003-0379-8604

Scopus ID: 16422942200

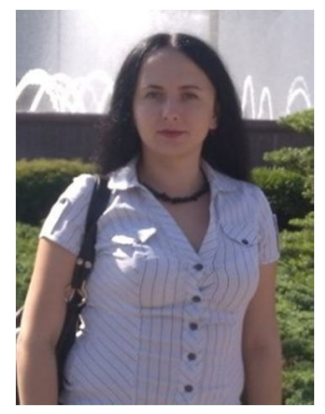

\section{Юзькова Валентина Дмитрівна.}

Кандидат хімічних наук, доцент кафедри методики викладання природничо-математичних дисциплін, Інститут післядипломної педагогічної освіти Чернівецької області, вул. Франка, 20, м. Чернівці, Україна, 58000.

Тел. 0952464709. E-mail: uzkovav@ukr.net

\section{Yuzkova Valentyna Dmytrivna.}

Cand.Sc. in chemistry, Associate Professor of Department of Natural and Mathematical Subjects Teaching Methodology, Chernivtsi In-Service Teacher Training Institute,

Franko str., 20, Chernivtsi, Ukraine, 58000.

Tel.0952464709. E-mail: uzkovav@ukr.net

ORCID: 0000-0002-7221-7650

Researcher ID: X-8995-2019

Scopus ID: 22137177400

\section{Citation (APA):}

Semchuk, A., Yuzkova, V. (2019). Problem-Solving in MS Excel as a Method of Some Key Competences Developing During the Study of Chemistry, Mathematics and Informatics in Secondary School Institutions. Engineering and Educational Technologies, 7 (4), 80-95. doi: https://doi.org/10.30929/2307-9770.2019.07.04.07

\section{Цитування (ДСТУ 8302:2015):}

Семчук А. Р., Юзькова В. Д. Розв'язування задач у MS Excel, як спосіб розвитку деяких ключових компетентностей, під час вивчення хімії, математики та інформатики у 33СО / Інженерні та освітні технології. 2019. Т. 7. № 4. С. 80-95. doi: https://doi.org/10.30929/2307-9770.2019.07.04.07

\footnotetext{
Обсяг статmі: $\quad$ сторінок-16; умовних друк. аркушів - 2,318.
} 